\title{
Imagens de mulheres negras e indígenas nos liuros didáticos dos territórios campesinos brasileiro e colombiano
}

\author{
Images of black and indigenous women from the textbooks of the \\ peasant territories of Brazilian and Colombian
}

\section{Imágenes de mujeres negras e indígenas en los libros didácticos de los territorios campesinos brasileño y colombiano}

\author{
Janssen Felipe Silua'
}

Universidade Federal de Pernambuco, Professor Associado I no Centro Acadêmico do Agreste no Curso de Licenciatura em Pedagogia e no Curso de Licenciatura Intercultural Indígena

\section{Anna Rita Sartore ${ }^{2}$}

Universidade Federal de Pernambuco, Professora Associada no Núcleo de Formação Docente e no Programa de Pós-Graduação em Educação Contemporânea

\section{Aline Renata dos Santos ${ }^{3}$}

\section{Universidade Federal de Pernambuco, Professora Substituta no Curso de Pedagogia do} Centro Acadêmico do Agreste

Resumo: Este artigo é um recorte da pesquisa de mestrado realizada no Programa de Pós-Graduação em Educação da Universidade Federal de Pernambuco e trata das imagens de mulheres negras e indígenas nos livros didáticos (LD) dos territórios campesinos do Brasil e da Colômbia. Objetivamos compreender os lugares e as funções das mulheres negras e das indígenas nas imagens dos LD. A lente teórica é o diálogo entre o Feminismo Latino-americano e os Estudos Pós-coloniais, e para a análise dos dados utilizamos a Análise de Conteúdo via Análise Temática (BARDIN, 2011) e a Semiótica (PEIRCE, 2005). Os resultados apontaram que os lugares e as funções de mulheres negras e indigenas retratadas nas imagens nos LD apresentam marcas da patriarcalização que se articulam à interseccionalidade de gênero, de raça-etnia e de território.

Palavras-chave: Imagens. Livros didáticos. Feminismo Latino-americano. Estudos Pós-coloniais.

Doutor e Mestre em Educação pela Universidade Federal de Pernambuco; http://orcid.org/0000-0001-8113-3478; http://lattes. cnpq.br/7400508587983938.

2 Doutora e Mestre em Educação pela Universidade de São Paulo; http://orcid.org/0000-0002-3688-6590; http://lattes.cnpq. $\mathrm{br} / 6541296069041830$.

3 Mestre em Educação pela Universidade Federal de Pernambuco; Doutoranda no Programa de Pós-graduação em Educação da Universidade Federal de Pernambuco; https://orcid.org/0000-0003-4483-3592; http://lattes.cnpq.br/0222046966698752. 
Abstract: This article as part of a master's dissertation in Post-Graduate Program in Education at the Education Centre of Federal University of Pernambuco, attempts to talk about how the black and indigenous women's image are represented in the didactic books of the Brazilian and Colombian peasant territories. We aim to comprehend these black and indigenous women's places and roles in those didactic books pictures. The theoretical lens is the dialogue between the Latin-American Feminism and the Postcolonial Studies. To analyze the data we used the Content Analysis by Thematic Analysis (BARDIN, 2011) and Semiotics (PEIRCE, 2005). The results indicated that the black and indigenous women's places and roles in the didactic books pictures have shown traces of patriarcalization that articulate to the intersectionality of gender, race-ethnicity and territory.

Keywords: Images. Didatic books. Latin American Feminism. Postcolonial Studies.

Resumen: Este artículo es un recorte de la investigación de maestría realizada en el Programa de Postgrado en Educación de la Universidad Federal de Pernambuco y trata de las imágenes de mujeres negras e indígenas en los libros didácticos (LD) de los territorios campesinos de Brasil y Colombia. Objetivamos comprender los lugares y las funciones de las mujeres negras y de las indigenas en las imágenes de los LD. La lente teórica es el diálogo entre el Feminismo Latinoamericano y los Estudios Postcoloniales. En el análisis de los datos utilizamos el Análisis de Contenido vía Análisis Temático (BARDIN, 2011) y la Semiótica (PEIRCE, 2005). Los resultados apuntaron que los lugares y las funciones de mujeres negras e indígenas en las imágenes de los $L D$ presentan marcas de la patriarcalización que se articulan a la interseccionalidad de género, de raza-etnia y de territorio.

Palabras clave: Imágenes. Libros didácticos. Feminismo Latinoamericano. Estudios post-coloniales.

Recebido em 9 de agosto de 2018 Aceito em 2 de abril de 2019 Publicado em 26 de abril de 2019

\section{INTRODUÇÃO}

Este artigo é um recorte da pesquisa de mestrado realizada no Programa de Pós-Graduação em Educação da Universidade Federal de Pernambuco e analisa as imagens de mulheres negras e indígenas nos livros didáticos (LD) dos territórios campesinos do Brasil e da Colômbia. Objetivamos identificar os lugares e as funções de imagens de mulheres negras e indígenas retratadas pelos livros didáticos e analisar as marcas de patriarcalização e de despatriarcalização presentes nas referidas imagens.

A análise está balizada no diálogo entre os Estudos Pós-coloniais (QUIJANO, 2005; MIGNOLO, 2011) e o Feminismo Latino-americano (PAREDES, 2011; SEGAT0, 2003). Essas abordagens questionam a "ego-política do conhecimento da filosofia ocidental, que 
privilegia o mito de um 'Ego' não situado, em que o lugar epistémico étnico-racial/sexual/ de género e o sujeito enunciador encontram-se, sempre, desvinculados." (GROSFOGUEL, 2008, p. 119). A ego-política do conhecimento tem reforçado a ideia de um conhecimento universal, masculino e neutro que se coloca como fundador de uma epistemologia única e válida, a eurocêntrica.

As abordagens teórico-metodológicas dos Estudos Pós-coloniais e do Feminismo Latino-americano vislumbraram a possibilidade de romper com o cânone eurocêntrico de produção de conhecimento ao desvelarem a geopolítica e a corpopolítica do conhecimento presentes na ciência moderna. A partir dessa ruptura, essas abordagens valorizam as epistemologias tecidas pelos sujeitos que historicamente tiveram seus territórios epistêmicos subalternizados por meio de processos de colonialismo e colonização (QUIJAN0, 2005). Esses sujeitos que estiveram à margem do cânone eurocêntrico passam a reivindicar os seus conhecimentos dentro de uma perspectiva outra, ou seja, das Epistemologias do Sul.

A escolha dos LD de História e de Geografia partiu do entendimento de que os LD de História possuem um papel relevante no processo de criação e cristalização de uma memória (BITTENCOURT, 2011) e de que os de Geografia "são produtores de uma dada sensibilidade e instauradores de uma dada forma de ver e dizer a realidade." (TONINI, 2001, p. 5). Nesse sentido, compreendemos esses livros enquanto fontes importantes para a identificação das marcas de patriarcalização e de despatriarcalização presentes nas imagens de mulheres negras e indígenas, uma vez que os LD compreendidos enquanto textos curriculares passam por uma seleção da cultura e nessa seleção são afirmados e/ou negados modos de ser mulher. Na nossa compreensão os LD são colonizados e colonizadores. Nessa linha de raciocínio, o modelo de ser mulher ainda está pautado no patriarcado imposto aos povos originários no período colonial e que sobrevive, na contemporaneidade, revestido de outras roupagens.

No Brasil, os livros didáticos para o território campesino foram escolhidos segundo o Edital de Convocação para o Processo de Inscrição e Avaliação de Obras Didáticas para o Programa Nacional do Livro Didático do Campo 2016 - Edital de Convocação 04/2014 - CGPLI. Analisamos os LD de História e de Geografia da coleção Novo Girassol Saberes e Fazeres do Campo da Editora FTD de São Paulo. Os LD destinados às escolas do território campesino da Colômbia são de responsabilidade do Estado colombiano. Este contratou a organização Corpoeducación ${ }^{4}$ para realizar a última atualização dos LD no ano 2010. A coleção dos LD da Colômbia são parte do programa escola nova.

\footnotetext{
4 Trata-se de uma organização de participação mista e de caráter privado. A sua missão é oferecer caminhos e soluções para
} melhorar a qualidade da educação. 
Apresentadas as fontes, faremos considerações sobre a nossa compreensão de imagem por intermédio do olhar da Semiótica Peirceana. Entendemos que as imagens presentes nos LD são constituídas por valores e ideologias que buscam preservar concepções de sociedade, elegendo determinadas raças, gêneros, culturas e territórios como sendo superiores a outros. Assim, "a produção de imagens jamais é gratuita e, desde sempre, as imagens foram fabricadas para determinados usos, individuais ou coletivos." (AUMONT, 1993, p. 78).

A partir de estudos de semiótica, sobretudo aqueles de Charles Peirce (2005), as imagens passam a ser entendidas como signos. Signo é algo que está no lugar de outra coisa, ou seja, é entendido como "aquilo que representa algo para alguém. Dirigese a alguém, isto é, cria na mente dessa pessoa, um signo equivalente, ou talvez um signo mais desenvolvido." (PEIRCE, 2005, p. 46).

Ainda de acordo com o autor, um signo é constituído por outros signos, ícones, índices e símbolos. 0 ícone "é um signo que se refere ao 0bjeto que denota apenas em virtude de seus caracteres próprios." Enquanto um índice "é um signo que se refere ao Objeto." Por fim, o símbolo "é um signo que se refere ao Objeto que denota em virtude de uma lei." (PEIRCE, 2005, p. 52). 0 caminho conceitual de Peirce orientou a seleção/ organização das imagens desse trabalho, respeitando os critérios e os princípios da Análise de Conteúdo, via Análise Temática de Bardin (2011), que acontece por meio de três fases: pré-análise, exploração dos dados, tratamento e inferências.

Na pré-análise, realizamos leituras flutuantes dos LD e selecionamos as imagens a partir da utilização das regras da exaustividade, da representatividade, da homogeneidade e da pertinência. Nessa fase, articulamos as regras citadas com a semiótica Peirceana a partir da qual elegemos imagens considerando a ocorrência de signos, ícones, índices e símbolos de interesse para a investigação, compondo os dados analíticos deste trabalho. Na exploração dos dados, classificamos e categorizamos as imagens selecionadas. Nessa fase, utilizamo-nos da tríade Peirceana para classificar as imagens, uma vez que estas são signos e, dessa forma, constituídas por ícones, índices e símbolos. Na fase de tratamento e inferências categorizamos as imagens agrupandoas por temáticas a fim de realizar inferências balizadas pelos Estudos Pós-coloniais e o Feminino Latino-americano.

Por fim, este trabalho é constituído por três seções, além da introdução e das referências, que são: diálogo entre os Estudos Pós-coloniais e o Feminismo Latinoamericano; lugares e funções das imagens de mulheres negras e indígenas focando as marcas de patriarcalização e de despatriarcalização e considerações finais. 


\section{DIÁLOGO ENTRE OS ESTUDOS PÓS-COLONIAIS E O FEMINISMO LATINO-AMERICANO}

0 diálogo entre os Estudos Pós-coloniais e o Feminismo Latino-americano advém da necessidade de desvelar as heranças coloniais instauradas no processo de colonialismo da Abya Yala, uma das nomeações atribuídas à América pelos povos Kuna, que "significa Terra Madura, Terra Viva ou Terra em florescimento e é sinônimo de América." (PORTO-GONÇALVES, 2009, p. 25). 0 colonialismo diz respeito à implementação arbitrária de uma nova ordem de poder, direta e formal, imposta por um povo "soberano", o europeu, sobre os povos inferiorizados. Além disso, esse colonialismo espalhou-se por meio da colonização dos povos e das culturas dominadas da América Latina. Para Quijano (2005), a colonização é uma etapa do colonialismo na qual se dá a imposição de formas de conhecimento, de trabalho, de cultura e de educação legitimadas como avançadas e superiores sustentadas por um ideal de sujeito branco, europeu, heterossexual, masculino e cristão.

0 referido autor advoga que o modelo eurocêntrico de dominação e de exploração empreendido pelos portugueses e espanhóis se sustenta em dois pilares fundamentais: a racionalização e a racialização. 0 primeiro diz respeito à hegemonia dos conhecimentos produzidos pelos europeus e das respectivas formas de produção, sendo considerados aqueles os únicos detentores e legitimadores de epistemologias válidas. 0 segundo modelo se dá por meio da construção simbólica da ideia de raça que classifica e hierarquiza os povos em raças superiores e inferiores e, mais especificamente, em brancos, índios, negros, mestiços e, posteriormente, a classificação de amarelos, acrescida às anteriores.

Mesmo com a "descolonização" da América, ao deixar de ser colônia, o padrão mundial de poder eurocêntrico, colonial, moderno, patriarcal e capitalista não findou, permanecendo até a atualidade; este encontrou novas formas de travestir-se para conservar a sua dominação. Dessa maneira, o colonialismo deixa como herança a colonialidade que é um processo arbitrário de dominação/exploração no qual o ideário colonial penetra as estruturas sociais tanto na dimensão objetiva quanto na dimensão subjetiva dos povos subjugados. Para Quijano (2005), há três eixos da colonialidade: do poder, do saber e do ser, que são imbricados entre si.

A colonialidade do poder refere-se à classificação e à hierarquização racial dos povos em inferiores e em superiores, o que determina a distribuição e o controle do trabalho dos povos subalternizados mundialmente. Atrelada a essa colonialidade, temos a colonialidade do saber que implica a negação e a invalidação dos conhecimentos 
dos não europeus. Esse eixo da colonialidade legitima uma razão que produz um conhecimento neutro-hegemônico-eurocêntrico-masculino e universal, por isso, válida.

Seguindo essa linha de raciocínio, os LD podem também ser portadores da colonialidade do saber ao reproduzir e valorizar as estruturas de poder fundadas pelo patriarcado ao tomar como válidos apenas os conhecimentos produzidos pelos homens brancos, negando as produções epistêmicas desenvolvidas pelas mulheres (CAROSIO, 2014). Cabe destacar que as mulheres brancas também eram vistas como seres sem razão em relação ao homem europeu-branco-burguês-patriarcal, no entanto essas mulheres eram superiores às mulheres indígenas e negras.

Os povos subalternizados são tidos como primitivos, irracionais, iletrados e sem cultura, incapazes de ter epistemologias válidas que produzam conhecimentos verdadeiros. A produção intelectual desses povos é entendida como senso comum; essa definição ratifica a hegemonia dos europeus sobre os povos inferiorizados. Ao determinar o que é senso comum, os europeus estão definindo, simultaneamente, o que é conhecimento científico e autoafirmam o seu poder epistêmico. Diante dessa autoafirmação, os europeus legitimam-se como os civilizados e de cultura letrada, em detrimento dos demais povos como não civilizados e de cultura não letrada, e tratam de desvalorizar a cultura oral dos povos subalternizados.

Essas manifestações da colonialidade consolidam-se na colonialidade do ser, que é a internalização da subalternidade do não europeu, passando a aceitar a imagem do colonizador como sua, ocultando a dominação colonial, o que Freire (2005) denomina condição do oprimido enquanto hospedeiro do opressor. Esse eixo da colonialidade nega a condição humana dos povos subalternizados, uma vez que estes nunca chegarão a ser europeus, "de esa manera seguimos siendo lo que no somos. $Y$ como resultado no podemos nunca identificar nuestros verdaderos problemas, mucho menos resolverlos, a no ser de una manera parcial y distorsionada." (QUIJAN0, 2005, p. 226). Assim, a colonialidade do ser consolida a condição de não sujeito que mira almejar o que jamais poderá ser.

Nesse contexto de dominação, a colonialidade reestrutura e sustenta o poder colonial. Porém, isso não acontece de maneira pacífica; os povos atingidos pela dominação colonial e consequentemente pela colonialidade criam resistências a essa dominação. Nessa direção, os povos da Abya Yala resistem a essa dominação ao se organizarem, coletivamente, para reivindicar o seu lugar como território epistêmico que possui suas heterogeneidades e, assim, dinâmicas sociais, políticas organizativas outras.

Mignolo (2011) chama a atenção para a relação conflitiva entre os "povos civilizados" e os "não civilizados" que resultou na diferença colonial que é constituída 
por tensões resultantes do contato direto entre duas histórias locais: a dos povos colonizados e a dos colonizadores, esta última tida como hegemônica.

No espaço da diferença colonial, os povos subalternizados apropriam-se da lógica europeia para dialogar em igualdade com a cultura tida como hegemônica, universal e válida. Esse diálogo visa restituir aos povos subalternizados o direito de narrar-se a partir de seus modos de vida e conhecimentos outros. Nessa direção, esses povos buscam fraturar a estrutura de dominação colonial e, ao fraturá-la, ganhar espaço para a valorização e a legitimação dos seus conhecimentos.

Nesse cenário de lutas por emancipação, a diferença colonial representa - estabelecimento de relações conflitivas e dialógicas de lócus de enunciação. As formas de pensamento e de conhecimentos, decorrentes desse contexto de diferença colonial, são caracterizadas por tecerem resistências propositivas em meio ao contexto de dominação colonial. Por isso que os movimentos negros e indígenas da América Latina, em especial, mantêm-se firmes em denunciar, por exemplo, o racismo presente no sistema escolar e anunciar a necessidade de um currículo pautado nos princípios da educação das relações étnico-raciais. No caso particular dos indígenas, há reivindicação de uma educação específica, diferenciada e intercultural.

Diante da necessidade de romper com a dominação colonial, surge a discussão sobre a interculturalidade que tem se intensificado nos últimos anos dentro dos Movimentos Sociais. Estes entendem a interculturalidade como ferramenta de luta no diálogo conflitivo entre culturas, na reivindicação do direito à diferença. Walsh (2008) e Sartorello (2009) apontam que a interculturalidade pode ser compreendida em duas perspectivas distintas, porém interligadas: a funcional e a crítica.

A perspectiva de interculturalidade funcional não intenciona romper com os moldes de dominação eurocêntricos, visa apenas a integrar os sujeitos à ordem social vigente, ou seja, ao padrão mundial de poder. Essa perspectiva de interculturalidade tem por objetivo amenizar os conflitos sociais, promovendo uma "emancipação social" limitada aos povos e grupos sociais subalternizados. É limitada no sentido de que os moldes eurocêntricos de dominação permanecem quase intactos, adornando uma igualdade social deficiente, que, na maioria das vezes, apenas alimenta os estereótipos geradores das desigualdades: histórica, social, política, epistemológica e educacional. Um exemplo disso é a celebração, nas escolas, de datas comemorativas como dia do índio, da consciência negra, entre outras, representando esses grupos sociais como cristalizados e naturalizados dentro do período colonial. Os índios apresentados com pouca roupa, com cocar e penas na cabeça. Os negros acorrentados "fantasiados" de escravos, ou seja, esses grupos sociais estão sendo celebrados, mas dentro de 
uma visão funcional ao sistema; não são protagonistas das lutas por libertação e emancipação do poderio colonial.

Assim, a interculturalidade funcional é a oficialização da diferença pelos governos neoliberais, a partir dos anos finais da década de 1990, dentro da lógica assistencialista de controle social e que não almeja transformar as estruturas de poder sustentadas pela colonialidade. Ao contrário, reforça e camufla ainda mais as desigualdades por elas estabelecidas.

A perspectiva de interculturalidade crítica busca elucidar as relações sociais desiguais, a fim de contribuir para um processo de transformação social que enalteça vozes outras. É entendida como um projeto político que visa à descolonialidade, à transformação e à criação de sociedades libertas do poderio colonial. Assim, a interculturalidade crítica é estabelecida por meio do diálogo conflitivo entre as diversas culturas.

Nessa perspectiva, a possível presença da despatriarcalização no livro didático é um indício da interculturalidade crítica, indo além do reconhecimento e da oficialização da diferença de gênero. As mulheres racializadas da Abya Yala apontam para a necessidade de propor concepções de educação que valorizem as complexidades existentes nas várias culturas, tendo em vista que buscam o desenvolvimento de formas organizativas educativas específicas, pressupondo práticas pedagógicas outras.

0 Feminismo Latino-americano vem realizando rachaduras políticas e epistêmicas ao denunciar as formas de exploração e opressão sofridas pelas mulheres indígenas, negras e mestiças pobres da Abya Yala. As Feministas da Abya Yala estão ancoradas em contextos específicos, em corpos e em territórios distintos que constituem contextos sócio-históricos, culturais e políticos em que realizam os seus quefazeres. Segundo Freire (1987, p. 70), “os homens são seres do quefazer é exatamente porque seu fazer é ação e reflexão. É práxis. É transformação do mundo. E, na razão mesma em que o quefazer é práxis, todo fazer do quefazer tem de ter uma teoria que necessariamente o ilumine. 0 quefazer é teoria e prática." 0 Feminismo Latino-americano realiza esses quefazeres questionando as configurações históricas e sociais que as localizam na condição de mulheres racializadas. Para tanto, o referido Feminismo se funda em uma teoria-prática enraizada nas epistemologias tecidas em suas realidades sócio-históricas.

0 revide epistêmico do Feminismo Latino-americano religa o sujeito de enunciação ao lugar epistêmico, desvelando a colonialidade do saber. 0 Feminismo Latino-Americano busca, em suas práticas, romper com o patriarcado colonial moderno por meio de lutas contra "el heteropatriarcado, el racismo, la misoginia, la violencia cotidiana dirigida las mujeres racializadas." (ESPINOSA MIÑOSO et al., 2013, p. 407). Nessa direção, destacamos a importância de considerar o lócus de enunciação das mulheres 
do território campesino, tendo em vista que essas mulheres possuem não só as marcas das opressões impostas pelo patriarcado colonial moderno como também as marcas das resistências que caminham para a descolonização de seus corpos. Por isso analisar, em especial, as imagens de mulheres negras e indígenas dos LD do território campesino é compreender as tensões entre a colonialidade e a decolonialidade, entre a patriarcalização e a despatriarcalização tecidas no espaço da diferença colonial, interseccionalizadas pelas diferenças de gênero, de raça-etnia e de território.

Nessa direção, para compreendermos as teias que tecem as marcas de patriarcalização e de despatriarcalização presentes nas imagens de mulheres negras e indígenas, partimos de um breve percurso histórico da constituição familiar, desde os tempos mais remotos, que conformaram a compreensão de família hegemônica que temos atualmente.

A ideia de família que temos, na sociedade ocidental, foi resultado de transformações sociais, culturais e políticas ocorridas durante toda a história. Essas transformações aconteceram de formas distintas; não havia um modelo de organização social único. De acordo com Narvaz e Koller (2006, p. 49-50), "família não é algo biológico, algo natural ou dado, mas produto de formas históricas de organização entre os humanos."

Na linha de raciocínio das autoras citadas, podemos afirmar que família é uma invenção social, cultural, histórica e política, que se configurou (configura) de distintas maneiras a depender das necessidades dos grupos de humanos em dado contexto sócio-histórico. Uma das formas de constituição familiar é a família patriarcal, que se estabeleceu como o padrão ideal de família, principalmente nas colônias portuguesas e espanholas instauradas nas terras da Abya Yala.

Ariès (1986) evidencia que as primeiras imagens de famílias passam a ser retratadas na iconografia medieval, por volta do século XVI. Inicialmente as iconografias apresentavam imagens de homens ligados ao ofício; com o passar do tempo foram sendo acrescidas imagens de mulheres e de crianças. Ele aponta que as primeiras iconografias retrataram cenas cotidianas familiares.

De acordo com Ariès (1986), as cenas familiares com o decorrer dos tempos passaram a não só ilustrar a imagem da família, como também dizer dos papéis de gênero atribuídos a cada membro da família. As imagens que retratavam o sentimento da família também denotavam os papéis sociais ordenados por meio do gênero. Essas imagens de família e de sentimentos ainda permanecem, a nosso ver, como heranças do processo de colonialismo e colonização. 
Ressaltamos que houve (há) famílias que fogem a esse padrão centrado na autoridade masculina. Durante toda a história houve modelos de famílias chefiados por mulheres centradas na descendência feminina (NARVAZ; KOLLER, 2006). No entanto, dizem as teorias que nunca houve um período histórico matriarcal em que as mulheres fossem, de fato, o gênero dominante, ou seja, mesmo quando as famílias eram chefiadas por mulheres, estas não possuíam domínio sobre os homens. Segundo Delgado e Franco (2014, p. 97), "lo que sí existieron, fueron sociedades donde las mujeres disfrutaron mayores niveles de igualdad sustantiva frente a los hombres, en la cual la posición de la mujer era más respetada y valorada." Na organização social dos grupos, as mulheres tinham um papel importante na reprodução da espécie e como guardiãs da descendência.

0 modelo de família patriarcal foi transposto aos povos da Abya Yala por meio da herança cultural, produto da união da cultura misógina greco-latina e da cultura misógina judaico-cristã, herdadas pelos espanhóis e portugueses. Delgado e Franco (2014, p. 104) assinalam que "la familia y el matrimonio constituyeron dos instituciones fundamentales de la colonización europea, ya que a través de ellas el Estado Monárquico y la Iglesia Católica, preservaban el orden establecido, la sociedad estamental trasplantada a este continente."

Saffioti (2015) realça que o patriarcado não está restrito apenas ao modelo de família patriarcal, visto que ele atravessa a sociedade como um todo. Nesse sentido, o patriarcado, atualmente, não assinala apenas a autoridade do pai sobre a família, mas o poder dos homens/masculino sobre as mulheres/feminino.

Destacamos que os corpos de mulheres foram oprimidos de formas distintas. Delgado e Franco (2014) compreendem que no caso da mulher branca recai sobre seu corpo a opressão de gênero, mas no que diz respeito às mulheres índias e negras estas sofriam (sofrem) as opressões decorridas da origem de raça, de etnia, de gênero, de classe e de território.

Evidenciamos que essas formas de opressão sobre as mulheres permanecem celebrando o mito de superioridade do homem. Paredes (2011) evidencia que o patriarcado colonial/moderno é um sistema de morte construído historicamente sobre o corpo das mulheres. Esse engloba costumes, tradições, normas, hábitos, ideias, símbolos, leis, entre outros, e determina, naturaliza e universaliza papéis e lugares das populações, das mulheres e dos homens em diferentes tempos e lugares. Nessa direção, Saffioti (1987, p. 8, grifo do autor) aponta que 
cumpridos pelas diferentes categorias de sexo. A sociedade delimita, com bastante precisão, os campos em que pode operar a mulher, da mesma forma como escolhe os terrenos em que pode atuar o homem.

Percebemos que há uma relação intrínseca entre a constituição da identidade da mulher e da identidade do homem; contudo, essa relação é assimétrica, pois no patriarcado a mulher é considerada como outro, ou seja, a exterioridade do homem, portanto, inferior. Essa atribuição de papéis e lugares é demarcada por um processo que localiza tanto as mulheres quanto os homens dentro de uma pretensa naturalidade. É natural as mulheres pertencerem ao espaço doméstico (reprodução), tanto quanto é natural aos homens serem identificados com o espaço público (produção). Sobre isso, Saffioti (1987, p. 9, grifo do autor) afirma que "a sociedade investe muito na naturalização deste processo. Isto é, tenta fazer crer que à atribuição do espaço doméstico a mulher decorre de sua capacidade de ser mãe."

A divisão do espaço doméstico tido como naturalmente feminino e do espaço público concebido como masculino estabeleceu uma separação e hierarquia entre a vida privada e a vida pública. "Aos homens, seres imaginados como racionais por excelência, foi dado o direito de consentirem em participar da esfera pública, igualitária e livre. As mulheres, vistas como carentes de razão, deveriam permanecer no lugar que lhes seria 'natural': a esfera privada" (MATOS; PARADIS, 2014, p. 66, grifo do autor). Uma das formas de socialização e conformação dessas identidades é mediante a educação escolarizada via currículos colonizados, ${ }^{5}$ portanto, patriarcais-racistas-capitalistas.

Os processos de socialização e manutenção de modos de ser mulher e de ser homem também não acontecem de forma simétrica. Segundo Saffioti (1987, p. 11, grifo do autor), "compreender como a naturalização dos processos socioculturais de discriminação contra a mulher e outras categorias sociais constitui o caminho mais fácil e curto para legitimar a "superioridade" dos homens, assim como a dos brancos, a dos heterossexuais, a dos ricos."

Entendemos ser fundante desvelar os processos de naturalização da condição das mulheres como inferiores aos homens, bem como evidenciar que as diferenças não estão restritas à diferença de gênero; esta é uma das diferenças que se articulam na subordinação de mulheres em relação aos homens, mas ainda podemos citar as diferenças intragênero (mulher-mulher; homem-homem).

Com relação a essa discussão, Saffioti (1987, p. 16) assinala que

Sobre esse assunto ver Ferreira e Silva (2014). 
há homens que dominam outros homens, mulheres que dominam outras mulheres e mulheres que dominam homens. Isto equivale a dizer que o patriarcado, sistema de relações sociais que garante a subordinação da mulher ao homem, não constitui o único princípio estruturador da sociedade brasileira.

Desse modo, compreendemos que a articulação entre patriarcado-racismocapitalismo na manutenção e na socialização do sistema mundo patriarcal-colonialmoderno-capitalista constitui a face da mesma moeda, ou seja, a modernidade/ colonialidade. Seguindo essa linha de pensamento, “a 'modernidade' é uma narrativa complexa, cujo ponto de origem foi a Europa, uma narrativa que constrói a civilização ocidental ao celebrar as suas conquistas enquanto esconde, ao mesmo tempo, o seu lado mais escuro, a 'colonialidade'." (MIGNOLO, 2017, p. 2). Nessa direção, entendemos que a modernidade se configurou a partir de uma ego-corpo-política masculina, patriarcal e racial.

Segundo Matos e Paradis (2014), atualmente vivenciamos um patriarcado contemporâneo. Contudo, as autoras ressaltam que "a diversidade da história ocidental das posições políticas das mulheres, em permanente contextualização, transformação e de contradições, dificilmente pode ser remetida à exclusividade da ideia unitária ou totalizante de um único patriarcado." (MATOS; PARADIS, 2014, p. 69).

Os Movimentos Feministas estão trilhando um caminho em busca da despatriarcalização do Estado por meio da ocupação dos espaços políticos e das lutas por formulações de políticas públicas que primem pela igualdade para as mulheres, sem que sejam desconsideradas as diferenças intragênero.

Nessa direção, a educação escolarizada possui um papel importante na luta contra o patriarcado. Logo, os livros didáticos enquanto textos curriculares podem ser um instrumento na busca pela despatriarcalização, visto que ele, como parte constitutiva do currículo escolar, carrega os anseios do Estado no tocante à formação dos cidadãos.

0 LD é território da diferença colonial, haja vista que a inclusão de imagens de mulheres nesses textos curriculares é resultado de lutas, sobretudo dos Movimentos Feministas. Foram as lutas de mulheres contra o poderio patriarcal que possibilitaram não só a inclusão de imagens de mulheres nos LD, mas a construção de uma legislação específica, como é o caso do Brasil e da Colômbia, que possuem políticas públicas para as mulheres que estabelecem a necessidade de que os LD não reproduzam conteúdos e/ou imagens de discriminação de gênero, raça, etnia, sexualidade e geração. 


\section{LUGARES E FUNÇÕES DAS IMAGENS DE MULHERES NEGRAS E INDÍGENAS: FOCANDO AS MARCAS DE PATRIARCALIZAÇÃO E DE DESPATRIARCALIZAÇÃO}

Nesta seção tratamos dos lugares e das funções que as imagens de mulheres negras e indígenas ocupam nos livros didáticos dos territórios campesinos do Brasil e da Colômbia. No tocante aos lugares identificamos cinco, sendo eles: família, escola, trabalho, comunidade e lazer. Com relação às funções identificamos as seguintes: esposa-mãe, doméstica, agricultora, artesã, extrativista, vendedora, coadjuvante e protagonista.

Com relação às imagens de mulheres negras, identificamos que elas ocupam todos os lugares encontrados e que as funções indicam marcas de patriarcalização e de despatriarcalização, atreladas à interseccionalidade de gênero, raça e território. No tocante às imagens de mulheres indígenas, percebemos que há uma ausência e/ou silenciamento nos lugares identificados, uma vez que as imagens de mulheres indígenas foram encontradas apenas nos lugares família e trabalho informal. A título de organização seguiremos as análises de acordo com a ordem dos lugares.

No que diz respeito às imagens que representam mulheres negras e indigenas nas funções citadas, categorizamos o lugar família como nuclear tradicional. No que diz respeito à função esposa, identificamos imagens de mulheres negras e indígenas e selecionamos uma imagem correspondente a cada mulher.

A partir da tríade peirceana, evidenciamos que as Imagens 1 e 2 correspondem ao signo lugar família e o caracterizamos como família nuclear tradicional. Nestas imagens as mulheres exercem a função de esposa e de esposa-mãe.

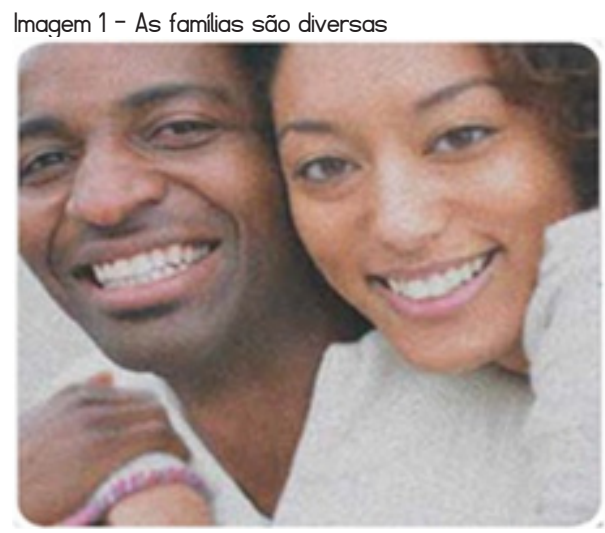

Fonte: Colômbia (2011a, p. 37). 


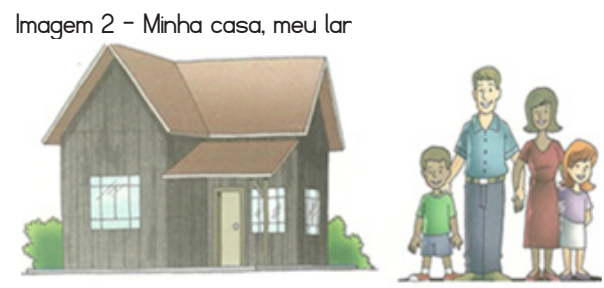

Fonte: Mares e Almeida (2014a, p. 106).

Este modelo de família, retratado nas Imagens 1 e 2, atrela-se à colonialidade do poder, uma vez que há uma imposição/naturalização do padrão heterossexual, como norma e elemento estruturante da família nuclear tradicional, reforçando a patriarcalização.

Não encontramos em nenhum dos livros uma composição de par diferente daquele heterossexual, fato que silencia outras orientações sexuais e constituições familiares. Em nosso entendimento, essas imagens caminham na contramão das orientações propostas pelas políticas destinadas a evitar o fortalecimento de estereótipos. Com relação ao Brasil, - III Plano Nacional de Políticas para Mulheres 2013-2015 discorre sobre a necessidade de "eliminar conteúdos sexistas e discriminatórios e promover a inserção de temas voltados para a igualdade de gênero e valorização das diversidades nos currículos, materiais didáticos e paradidáticos da educação básica." (BRASIL, 2013, p. 23, grifo nosso).

Nessa linha de raciocínio, o Decreto n. 166, de 2010, da Colômbia, que trata da adoção da política pública de mulheres e equidade de gênero, aponta para a necessidade de "promover el reconocimiento de la diversidad de las mujeres que habitan en el Distrito Capital, relacionadas con generación, cultura, etnia, identidad campesina, [...] territorio, orientación sexual." (COLOMBIA, 2010, p. 10, grifo nosso).

Diante desses extratos salientamos que as legislações, tanto do Brasil quanto da Colômbia, têm primado pela busca de equidade e por uma educação não sexista e despatriarcalizada, valorizando as distintas formas de vivência de gênero e da sexualidade, o que nem sempre se materializa nas imagens que ilustram os livros.

No que diz respeito à Imagem 2, apontamos ambivalências, pois nela há marcas da despatriarcalização e da patriarcalização. As marcas de despatriarcalização são duas: família inter-racial, o que não configura tradição e fissura na geopolítica patriarcal ao retratar o casal homem-mulher lado a lado, remetendo-nos a uma horizontalidade entre o casal, o que na família nuclear tradicional não seria "aceitável". Quanto às marcas da patriarcalização destacamos as seguintes: modelo de família nuclear tradicional, remetendo ao patriarcado e à divisão geopolítica a partir do gênero das personagens, menina ao lado da mãe e menino ao lado do pai. Essa divisão geopolítica dos corpos nos remete ao estudo 
de Ariès (1986) sobre as primeiras iconografias retratando a familia a partir do século XV, levando-nos a perceber as influências que ainda permanecem nos LD do Brasil, tendo em vista que até a década de 1930 os livros didáticos destinados às escolas brasileiras eram importados da França.

Vale dizer que a mulher negra retratada apresenta características mais comuns da raça branca, como, por exemplo: o cabelo liso e os lábios finos. Isso pode indicar uma tendência não incomum, sobretudo no passado, de enaltecer um embranquecimento, nesse caso da personagem, negando determinados fenótipos característicos de diferentes origens étnico-raciais. Essa tendência ao embranquecimento da personagem indica a presença da interculturalidade funcional e da colonialidade do ser, pois mantém uma posição subalterna na medida em que foi ilustrada em um processo de embranquecimento para se aproximar da raça branca, embora a diferença racial se apresente nas ilustrações dos LD, o que pode levar as estudantes negras a querer passar por esse processo de embranquecimento para se aproximar do padrão hegemônico racial.

As imagens de mulheres indígenas retratadas na função esposa-mãe estão presentes tanto no LD do Brasil quanto no LD da Colômbia, como podemos ver nas Imagens 3 e 4. Essas imagens retratam dois grupos de pessoas que, a partir da organização e do gênero dos grupos, ilustram o modelo organizacional de família nuclear tradicional caracterizado pela constituição-organização do grupo: pai, mãe, filhos e filhas, apontando marcas que compreendemos ser da patriarcalização, pois permanece o padrão normativo heterossexual, como única forma de organização familiar, como observamos na organização familiar das mulheres negras.

Frisamos que a representação da família indígena segundo o padrão de família nuclear tradicional denota a colonialidade do poder e de gênero. Do poder, pois há uma imposição de um padrão civilizatório tido como superior pautado no patriarcado. De gênero, visto que esse padrão está fundado em uma cosmovisão que toma por referência o olhar do homem-branco-heterossexual-cristão-europeu centro-fálico e da mulher é periférico-marginal em detrimento de cosmologias outras que não tenham por referência o gênero masculino.

Isso nos remete ao que diz Segato (2013) sobre o patriarcado pré-europeu: em razão da conquista das terras da Abya Yala, os europeus reforçaram o patriarcado já existente nessas terras e o tornaram de alta intensidade. Assim, onde existia certa "igualdade" entre os gêneros houve uma reconfiguração para atender ao homem-brancoheterossexual-cristão-europeu.

Paredes (2010) destaca que a invasão trouxe consigo o patriarcado europeu que se entroncou com o patriarcado dos povos originários. Esse entroncamento patriarcal 
comprometeu as relações "igualitárias" existentes entre as mulheres e os homens da Abya Yala. Com esse entroncamento patriarcal, essas mulheres foram progressivamente ignoradas e passaram a constituir a exterioridade na conformação da sociedade patriarcal, provocando a destituição do papel protagonista destas no mundo-aldeia (SEGAT0, 2003).

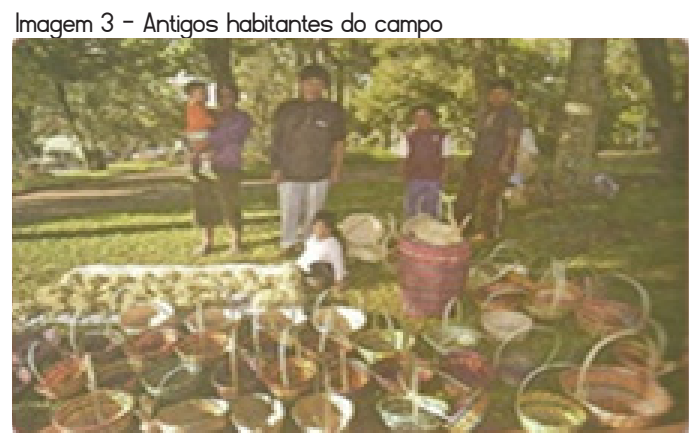

Fonte: Mares e Almeida (2014b, p. 176).

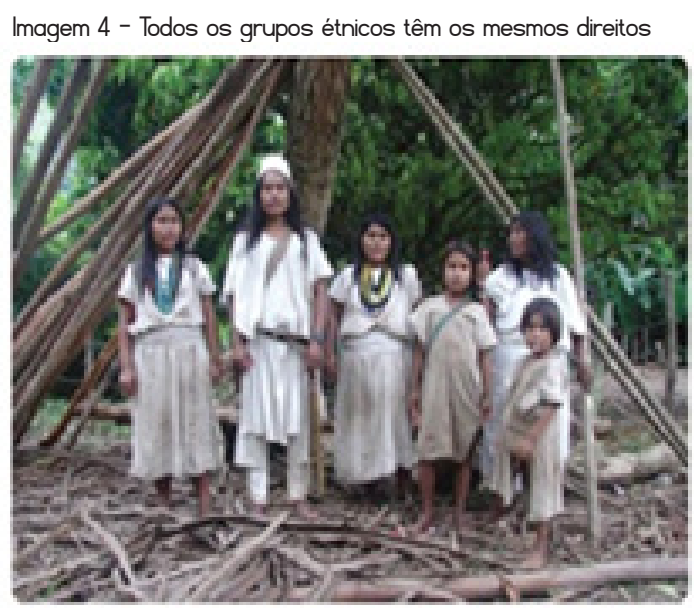

Fonte: Colômbia (2011c, p. 70).

Com relação ao lugar escola, identificamos apenas a mulher negra neste lugar, exercendo a função de estudante; as mulheres indígenas não são retratadas no referido lugar, conforme a lmagem 5. Prosseguindo com a análise triádica de Peirce, vemos na lmagem 5 indícios que nos levaram a interpretá-la como o signo/função estudante no tocante às imagens de meninas negras e de forma geral das outras personagens. 


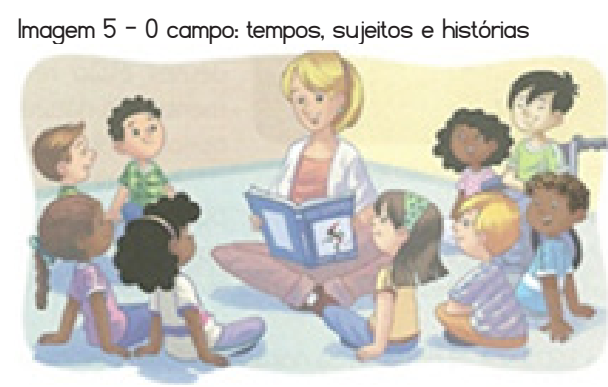

Fonte: Mares e Almeida (2014e, p. 169).

Percebemos que as mulheres ocupam espaços de poder, como é o espaço escolar, e que as mulheres negras transitam neste lugar, o que não ocorre com as mulheres indígenas, pois não identificamos nos livros analisados, tanto da Colômbia quanto do Brasil, a mulher indígena retratada nesse lugar e na função de estudante ou em outra função.

Esta constatação nos levou a perceber a presença da colonialidade do poder, do saber e do ser, uma vez que a partir do olhar do colonizador, ainda presente nos LD, as mulheres indígenas permanecem no passado colonial. Ou seja, são atreladas ao natural, seres sem razão. Entendemos que há um avanço com relação à presença de imagem de mulher negra na escola e na função estudante, contudo não identificamos imagens em que ela é professora ou assuma outras funções dentro da escola. Assim, o lugar escola retratado nos LD analisados ainda é o espaço da diferença colonial, bem como ainda é um espaço de silenciamentos e/ou negação da diferença existente em nossa sociedade, indicando que esse lugar não deve ser ocupado por todos, conforme podemos perceber com a ausência das mulheres indígenas na escola.

Com relação ao lugar trabalho o caracterizamos como trabalho informal lque se refere às atividades não regulamentadas por leis trabalhistas), identificamos imagens de mulheres negras e indígenas exercendo as seguintes funções: doméstica, artesã, extrativista, agricultora e vendedora.

A partir da tríade peirceana, atribuímos à Imagem 6 a atividade/signo cozinhar considerando os seguintes índices: vestimentas das personagens (avental e chapéu de padeiro), instrumentos de auxílio ao preparo da comida (rolo de massa, luvas) e alimentos (farinha, ovos).

A Imagem 6 carrega a marca da patriarcalização, isto acontece porque os LD ilustram imagens de mulheres exercendo uma função que está diretamente atrelada às atribuições do gênero feminino, na visão do patriarcado. Essas imagens reforçam um lugar geopolítico do trabalho das mulheres como de menor prestígio. 


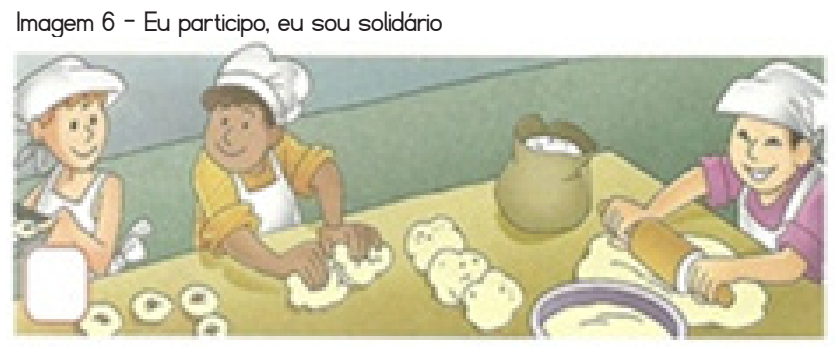

Fonte: Mares e Almeida (2014b, p. 186).

Dessa feita, entendemos que os LD reforçam um modo de ser mulher ao mostrarem imagens de mulheres em funções que coadunam para localizar seus corpos e suas subjetividades dentro do poderio patriarcal, pois mesmo quando as mulheres ocupam o espaço público do trabalho as funções desenvolvidas são extensão das realizadas no lar, como é o caso de cozinhar. Assim, percebemos que essa função carrega a colonialidade de gênero e do poder.

Com relação à atividade/signo buscar água, identificamos imagens no LD do Brasil e no LD da Colômbia. Essas imagens ilustram mulheres negras, conforme podemos observar nas Imagens 7 e 8.

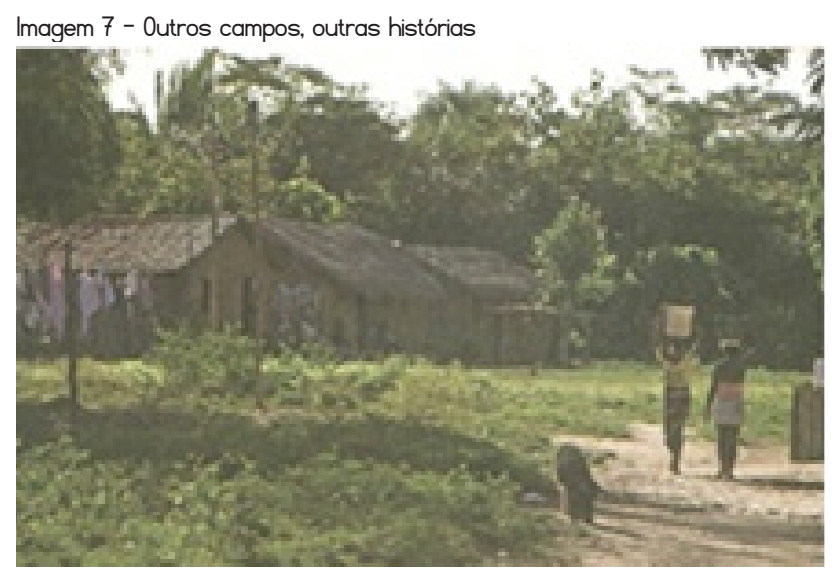

Fonte: Mares e Almeida (2014b, p. 175). 


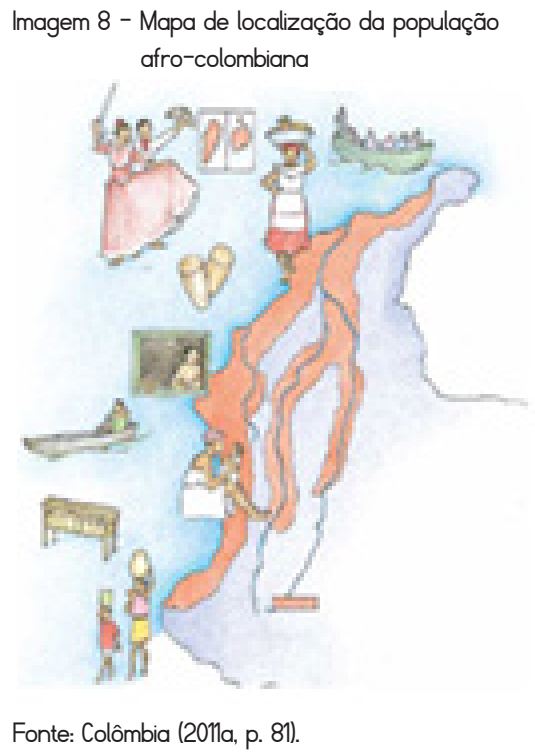

As Imagens 7 e 8 revelam que as marcas de patriarcalização se atrelam à interseccionalidade de gênero e de raça. De gênero, por vincular a mulher à manutenção e sobrevivência da prole por meio do abastecimento de água. De raça, porque são as mulheres não brancas que sofreram/sofrem com os efeitos do empobrecimento de seus territórios e de suas comunidades, resultante dos arranjos econômicos iniciados desde os processos de colonialismo e colonização.

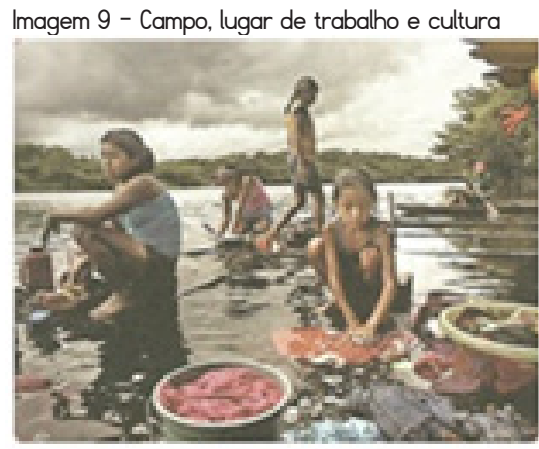

Fonte: Mares e Almeida (2014c, p. 169).

Visualizamos na Imagem 9 a atividade/signo lavar roupas. A essa atividade/ signo localizamos marcas da patriarcalização atreladas à racialização. A marca da patriarcalização decorre do fato de serem exclusivamente as mulheres representadas 
nessa atividade/signo, naturalizando ser essa uma atividade exclusiva do gênero feminino. A marca da racialização se desdobra em dois tipos, racialização das práticas sociais e culturais das mulheres indígenas e a racialização do território. Vemos que o LD generaliza as práticas sociais e culturais dessas mulheres, limitando-as às atividades domésticas, silenciando atividades outras realizadas pelas mulheres indígenas. Esse silenciamento é resultado da colonialidade de gênero, do poder e do saber. Quanto à racialização do território, identificamos que há uma relação hierarquizada, pois retratar o território apenas ligado às atividades de manutenção da vida localiza os povos indígenas estagnados no tempo, quando sabemos que os territórios indígenas são diversos e foram/são atingidos pelos processos de modernização (SEGAT0, 2013).

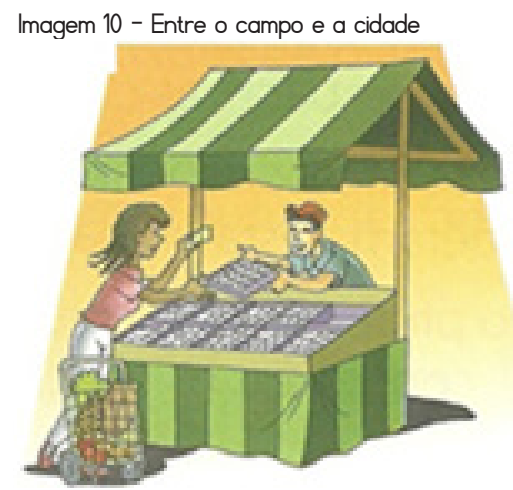

Fonte: Mares e Almeida (2014a, p. 136).

Quanto à atividade/signo comprar alimentos, encontramos imagem de mulher negra, conforme vemos na Imagem 10. Nesta encontramos marcas da patriarcalização; entendemos que essa atividade/signo evidencia a função reprodutora e sustentadora do lar, pois a atividade de comprar alimentos é tida como uma função da mulher dentro da família nuclear tradicional. Assim, entendemos que os LD ainda primam pela manutenção e socialização de espaços separados pelos gêneros.

Conforme vimos, o trabalho doméstico é compartilhado tanto pela mulher negra quanto pela mulher indígena, denotando que as funções de reprodução e manutenção da família estão, exclusivamente, sob a responsabilidade das mulheres, remetendo-nos à matriz de poder patriarcal-colonial-moderna-capitalista, que por meio da colonialidade de gênero situou/situa as mulheres negras e indígenas dentro de um padrão homogeneizador de ser mulher, ignorando formas outras de divisão e de compartilhamento da vida. 
Identificamos a função/signo artesã nos LD do Brasil e nos LD da Colômbia. Essa função divide-se em três tipos de ocupações: rendeira, tecelã e ceramista, conforme podemos observar nas Imagens 11, 12 e 13. Essas atividades são comuns tanto às mulheres negras quanto às indígenas, porém as formas de retratar cada mulher nessas atividades são distintas, desvelando a patriarcalização e a racialização.

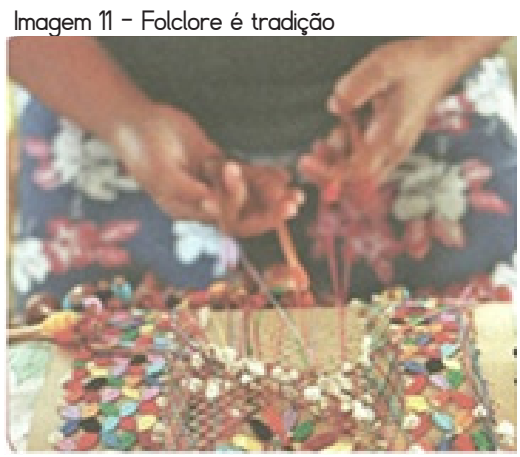

Fonte: Mares e Almeida (2014d, p. 165).

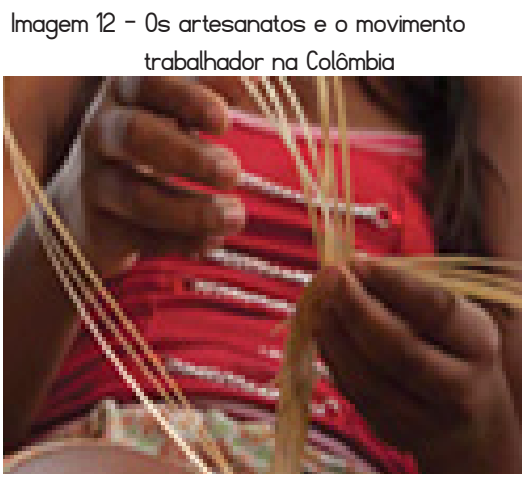

Fonte: Colômbia (2011d, p. 47)

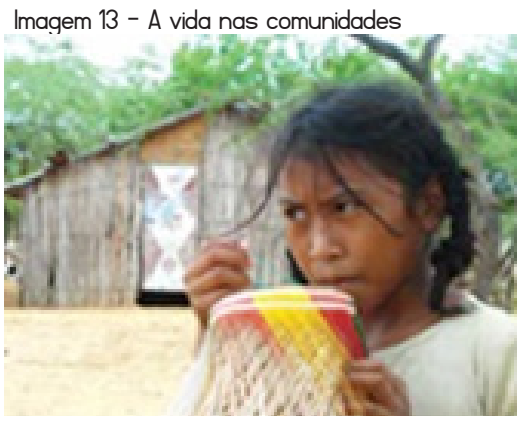

Fonte: Colômbia (2011a, p. 81). 
A nosso ver, as imagens de mulheres negras e indígenas sofrem com a marca da patriarcalização, pois o trabalho de rendeira e de tecelã historicamente foi/é socializado como um trabalho feminino realizado no espaço doméstico. Essa socialização revela uma hierarquia entre trabalho manual e trabalho intelectual, tendo em vista que para as mulheres o trabalho realizado fora do espaço doméstico é apresentado nos LD como uma extensão do trabalho no lar. Assim, vemos que essas imagens delimitam o campo de atuação feminina ao trabalho manual, uma vez que para fazer renda não é preciso uma educação escolarizada qualificada, o que denota a patriarcalização e a colonialidade do saber.

Concernente à marca da racialização, vemos que nas Imagens 1 e $१ 2$ a mulher negra não teve o seu rosto retratado apenas suas mãos, e as imagens não trazem um cenário maior para que possamos compreender onde ela se localiza. Entendemos que essas imagens remetem à racialização em que a raça tida como inferior não precisa estar dentro de um contexto. Para a mulher negra só se enfatiza a atividade que está sendo realizada, ignorando o ser que a realiza.

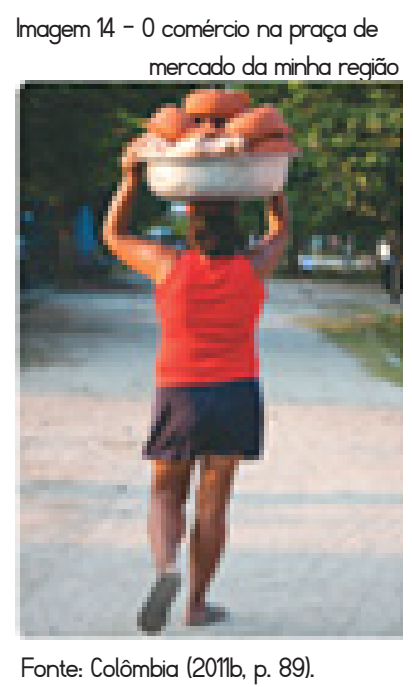

Com relação à Imagem 13, identificamos indícios da racialização, pois a imagem apresenta o território e a mulher indígena atrelados à pobreza. Essas imagens reproduzem a classificação e a hierarquização racial instaurada no processo de colonialismo e colonização, em que a raça branca é tida como superior, a indígena é inferior à raça branca e a raça negra é inferior a ambas, pois se localiza na base de todas as subalternizações. 
Prosseguimos a análise e inferimos que a lmagem 14 corresponde ao signo ofício ceramista. Como nas funções de rendeira e de tecelã, identificamos marcas da patriarcalização atrelada à racialização.

A patriarcalização refere-se ao fato de esse trabalho não possuir status social e a ele é atribuído o status de trabalho de mulher, haja vista que ele é uma extensão do trabalho realizado no espaço doméstico. A racialização das imagens remete à diferença intragênero. É evidente a racialização do corpo negro, visto que a mulher negra é ilustrada de costas, indicando aspectos atrelados a um pensamento de que a mulher negra é grosseira-forte, naturalmente propensa para $\circ$ trabalho pesado. Pensamento tal que justificou/justifica práticas de subalternização/exploração da mulher negra.

A função extrativista nos LD, em especial do Brasil, revelou a articulação entre a patriarcalização e a racialização no momento em que retrata imagens de mulheres negras exercendo exclusivamente a referida função, denotando a permanência e manutenção do lugar subalterno destinado às mulheres negras por meio do trabalho manual e informal, conforme constatamos nas Imagens 15 e 16.

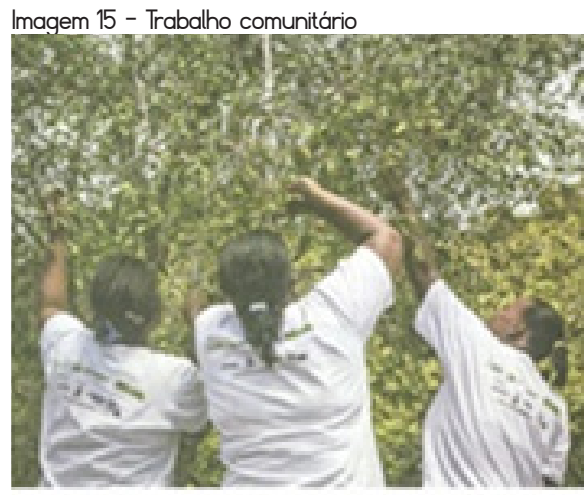

Fonte: Mares e Almeida (2014c, p. 174).

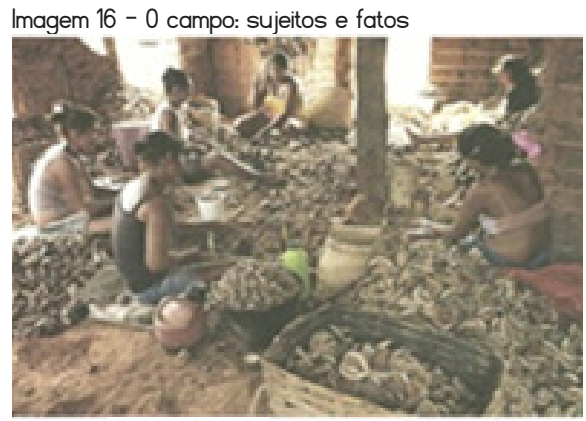

Fonte: Mares e Almeida (2014c, p. 177). 
A patriarcalização decorre do trabalho realizado, uma vez que o trabalho manual foi primordialmente destinado às mulheres, na visão patriarcal. Os postos de trabalho que exigissem o uso da razão estavam/estão destinados, preponderantemente, aos homens brancos.

Evidenciamos que essas imagens corroboram a manutenção das subalternizações impostas às mulheres negras, bem como revelam uma realidade ainda vivenciada por essas mulheres. Essas imagens evidenciam a racialização do trabalho, visto que a mulher negra que esteve/está limitada aos espaços profissionais de menor prestígio social e de menor remuneração, geralmente, ocupa postos de trabalho que se assemelham aos desenvolvidos no período da escravidão.

Referente à função agricultora localizamos imagens que retratam imagens de mulheres negras e indígenas. Inferimos que a Imagem 17 ilustra a mulher negra exercendo uma dupla função, a de agricultora e a de mãe. Essa constatação decorre do fato de que ela foi ilustrada com o corpo voltado em direção ao filho e à filha, indicando que estão sob sua responsabilidade. Desse modo, entendemos que há uma sobrecarga de trabalho da mulher, haja vista que ocupar o espaço público não a isenta da sua função de mãe; logo essa dupla função atrela-se à patriarcalização.

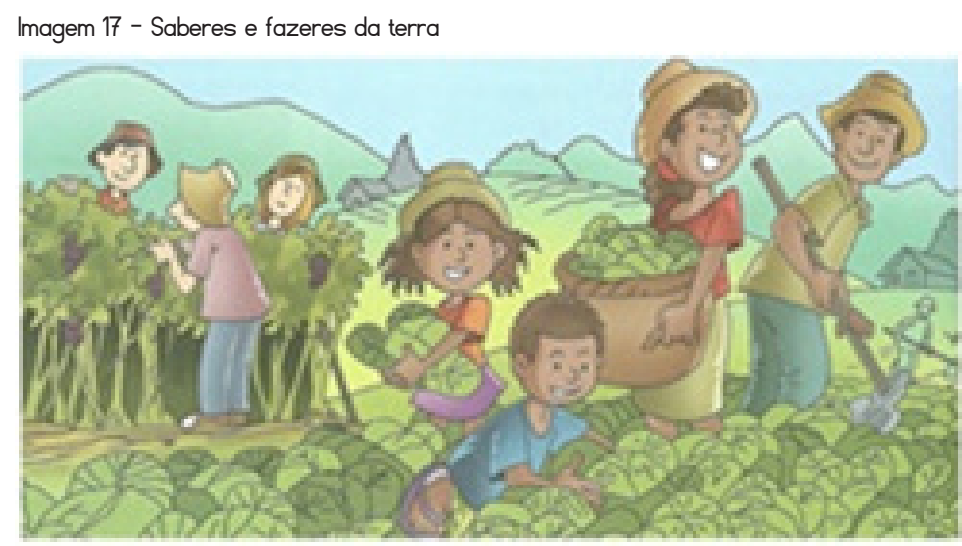

Fonte: Mares e Almeida (2014c, p. 158).

Com relação às mulheres indígenas exercendo a função de agricultoras, identificamos imagens no LD do Brasil e no da Colômbia, como podemos ver nas Imagens $१ ८$ e 19 . 


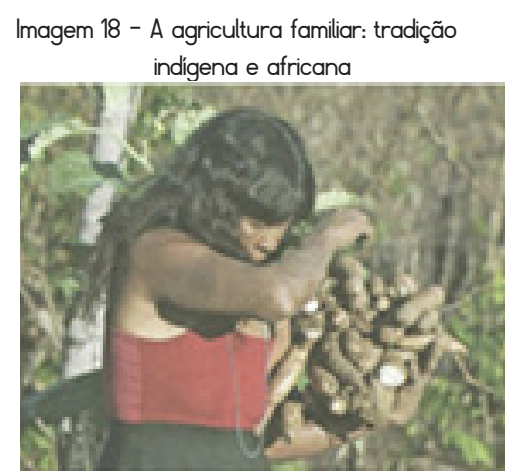

Fonte: Mares e Almeida (2014d, p. 177).

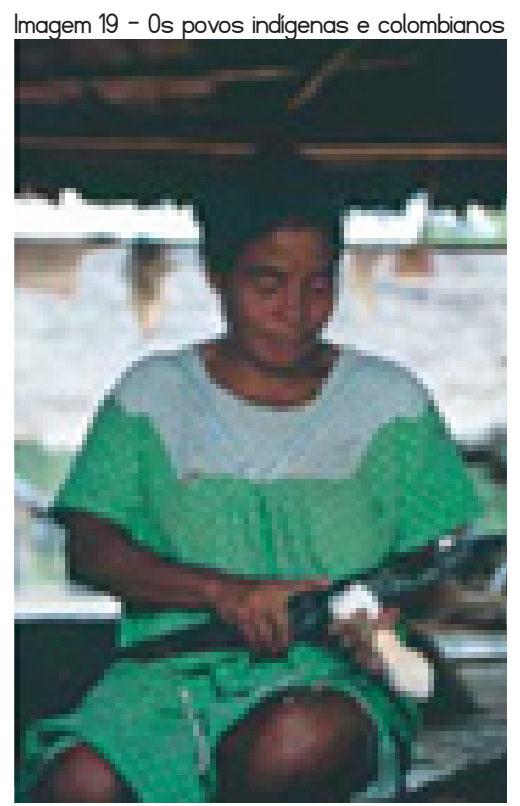

Fonte: Colômbia (2011d, p. 96).

Percebemos em ambas as imagens índices que sugerem trabalho na agricultura. Evidenciamos que essas imagens carregam marca da patriarcalização, da racialização e da colonialidade. A marca da patriarcalização decorre do fato de que as mulheres indígenas são ilustradas exercendo um trabalho tido como de menor valor, na visão patriarcal, como nas imagens anteriores. A racialização acontece na medida em que as mulheres indígenas são retratadas de forma a sugerir empobrecimento, além de estarem sós e longe da comunidade indígena, que, em geral, tem como um dos fundamentos a coletividade. A colonialidade se faz presente nas imagens por mostrarem mulheres indígenas, reforçando um estereótipo homogeneizador de povo indígena ligado ao plantio da mandioca, remetendo-nos que os 
povos indígenas permanecem estacionados no tempo apesar das mudanças históricas, culturais e econômicas que ocorrem. Frisamos que essas imagens remetem à representação de mulheres do terceiro mundo, retratada por Mohanty (2008), em que o olhar eurocêntrico enxerga essas mulheres como aquelas empobrecidas, sem conhecimento, atrasadas.

Com relação à função vendedora só encontramos imagens de mulheres negras nos livros didáticos do Brasil e da Colômbia, vejamos as Imagens 20 e 21. Nestas, percebemos marcas da patriarcalização e da racialização do trabalho e marca da despatriarcalização. A patriarcalização decorre do tipo de trabalho que a mulher negra exerce caracterizado por ser manual e informal, assim é um trabalho pouco prestigiado socialmente e precarizado. Essas características são uma constante nos trabalhos destinados às mulheres, em especial as não brancas.

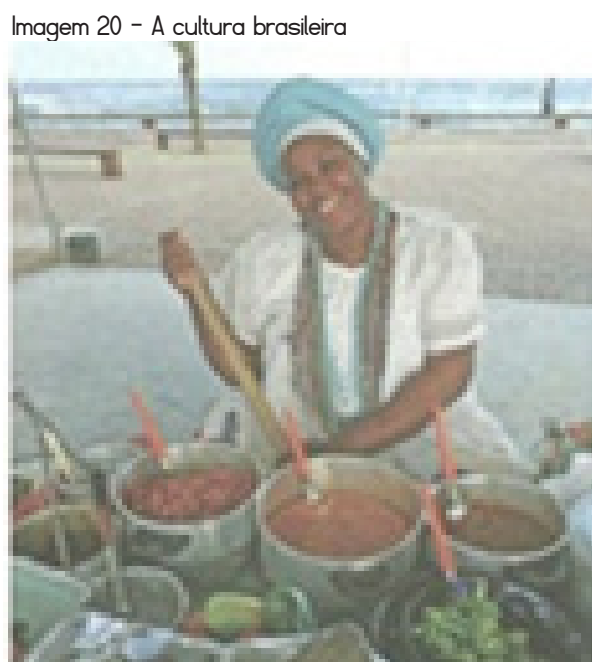

Fonte: Mares e Almeida (2014e, p. 162).

Imagem 21 - Como é o mercado nas áreas rurais?

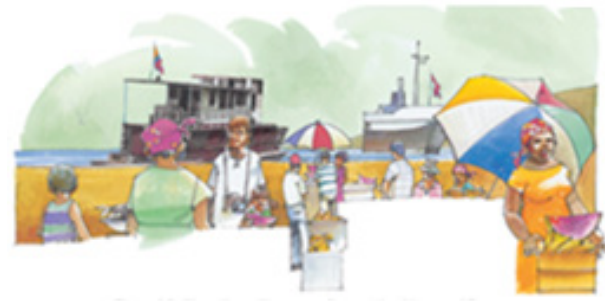

Fonte: Colômbia (2011d, p. 87). 
A racialização do trabalho segue a esteira da colonialidade, pois, mesmo com as transformações sociais relacionadas ao mundo do trabalho e às diversas profissões existentes, são as mulheres negras que ainda ocupam postos de trabalho similares ao período colonial, como é o caso de ser vendedora. A partir da compreensão de que as opressões não ocorrem sem que haja resistências, entendemos a função vendedora como um ato de resistência das mulheres negras, que, retiradas de seus territórios, criaram formas outras de resistir diante do patriarcado e da colonialidade de gênero, do saber e do ser.

No lugar comunidade, identificamos a função/signo coadjuvante; esta compreende aquelas imagens que remetem a um papel secundário das mulheres em momentos de organização e reivindicações da comunidade, como podemos observar nas Imagens 22 e 23.

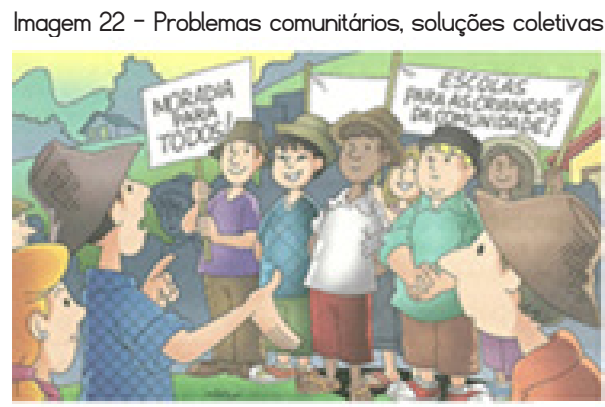

Fonte: Mares e Almeida (2014c, p. 189).

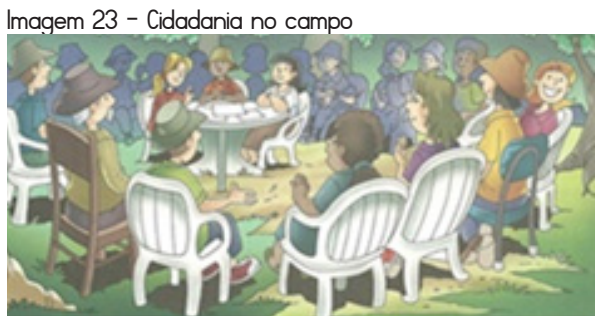

Fonte: Mares e Almeida (2014d, p. 181).

No lugar comunidade a marca da patriarcalização apresenta-se por meio de três aspectos: o primeiro corresponde à quantidade assimétrica entre homens e mulheres, o segundo decorre da função exercida pela mulher negra, em especial, que é a coadjuvante, o terceiro compreende o lugar geo-corpo-político ocupado pelas mulheres nas imagens.

Assim, entendemos que o fato de as Imagens 22 e 23 retratarem imagens de mulheres negras na comunidade não as coloca, necessariamente, em uma posição de protagonistas. Sobre essa questão, Segato (2003, p. 228) afirma que "estar de paso por esa historia, en tránsito, no significa ser protagonistas de esa historia. Esto determina una 
ambivalencia entre sentimiento de estar alli pero no ser de alli." Percebemos que as referidas imagens trazem índices da interculturalidade funcional e de relações de gênero fundadas no patriarcado, que se articulam para subalternizar as mulheres, pois estas são vistas como meras coadjuvantes. As mulheres estão para acompanhar e auxiliar os homens, seja na luta por melhorias da comunidade, seja para acompanhá-los nos momentos de convívio comunitário. Assim, estas imagens são o retrato da herança colonial patriarcal, isto é, da colonialidade de gênero imbricada à racialização de gênero.

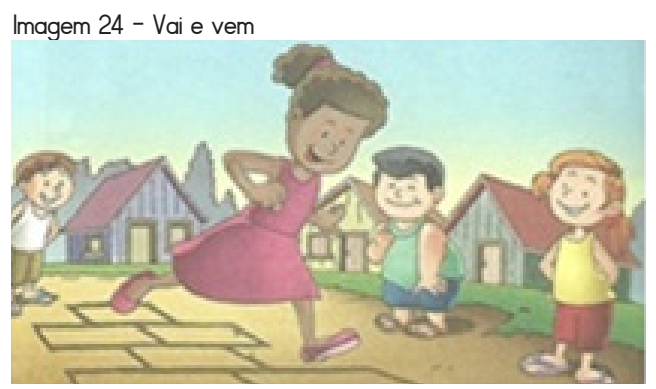

Fonte: Mares e Almeida (2014b, p. 170).

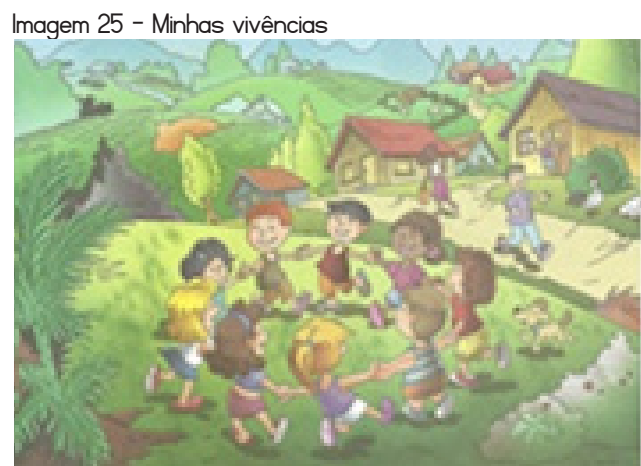

Fonte: Mares e Almeida (2014b, p. 147).

Sobre o lugar lazer encontramos imagens de mulher negra na função protagonista. Vemos que as Imagens 24 e 25 rompem com o patriarcado, principalmente, no tocante à divisão das atividades de lazer referenciadas mediante o gênero.

As Imagens 24 e 25 ilustram meninos e meninas compartilhando das brincadeiras conjuntamente, indicando paridade na relação, bem como simetria quantitativa em relação à ilustração de meninos e meninas. Assim, vemos que essas imagens denotam uma relação horizontal entre homens e mulheres. 
Saffioti (1987) evidencia que a atividade de lazer, assim como o trabalho, é algo que precisa ser compartilhado tanto por homens quanto por mulheres, uma vez que desvelar o pretenso caráter natural das discriminações amplia as possibilidades de romper com o patriarcado. Nessa direção, encontramos duas marcas de despatriarcalização nas atividades de lazer, são elas: representação quantitativa igualitária das personagens femininas e masculinas e partilha das brincadeiras entre meninos e meninas.

\section{CONSIDERAÇÕES FINAIS}

A partir das análises das imagens por meio da lente teórica dos Estudos PósColoniais e do Feminismo Latino-americano foi possivel tecer considerações a respeito das imagens de mulheres negras e indígenas dos LD dos territórios campesinos do Brasil e da Colômbia. Nossa análise apontou que as imagens de mulheres negras estão presentes nos cinco lugares (familia, escola, trabalho, comunidade e lazer) identificados; contudo as imagens de mulheres indígenas só foram identificadas nos lugares família e trabalho.

As funções de mulheres negras e indígenas retratadas nas imagens, nos referidos lugares, desvelaram uma pretensa naturalização de imagens dessas mulheres em funções subalternizadas, principalmente com relação às funções relativas ao trabalho. Conforme podemos analisar, os trabalhos de menor prestígio social ainda são exercidos pelas mulheres negras e indígenas. Nessa direção, os LD possuem uma tendência a reforçar/naturalizar esses trabalhos como sendo exclusivamente dessas mulheres, tomando por referência o gênero, bem como os territórios.

Destacamos que apesar da existência de uma legislação que orienta as editoras na formulação dos LD, evidenciando a necessidade de não retratarem estereótipos e discriminações de qualquer natureza, identificamos que ainda há imagens que carregam estereótipos e discriminações de gênero, raça/etnia e território. 0 que nos remete a inferir sobre a premência de uma fiscalização mais eficiente das coleções didáticas que são submetidas ao processo avaliativo do PNLD, no caso do Brasil.

Ademais, também, percebemos que há uma cultura patriarcal comum às mulheres negras e indígenas retratadas tanto nos LD do Brasil quanto nos LD da Colômbia. Logo, compreendemos que os LD disseminam a cultura patriarcal ao passo que reforçam a racialização das mulheres negras e indígenas. 


\section{REFERÊNCIAS}

ARIĖS, P. História social da criança e da família. Rio de Janeiro: Editora Guanabara, 1986.

AUMONT, J. A imagem. Campinas, SP: Papirus, 1993.

BARDIN, L. Análise de conteúdo. Lisboa: Edições 70, 2011.

BITTENCOURT, C. M. F. Ensino de História: fundamentos e métodos. São Paulo: Cortez, 2011.

BRASIL. III Plano Nacional de Políticas Públicas para as Mulheres. Brasilia, DF: Secretaria Especial de Políticas para as Mulheres Presidência da República, 2013.

CAROSIO, A. Feminismos para un Cambio Civilizatorio. Caracas, Venezuela: CLASCO, 2014.

COLOMBIA. Decreto n. 166, de 4 de mayo de 2010. Por el cual se adopta la Política Pública de Mujeres y Equidad de Género en el Distrito Capital y se dictan otras disposiciones. Bogotá, 4 maio 2010.

COLÔMBIA. Ministerio de Educación Nacional. Ciencias Sociales 2: Escuela Nueva. Bogotá, Colombia: Ministerio de Educación Nacional, 201la.

COLÔMBIA. Ministerio de Educación Nacional. Ciencias Sociales 3: Escuela Nueva. Bogotá, Colombia: Ministerio de Educación Nacional, 2011b.

COLÔMBIA. Ministerio de Educación Nacional. Ciencias Sociales 4: Escuela Nueva. Bogotá, Colombia: Ministerio de Educación Nacional, 2011c.

COLÔMBIA. Ministerio de Educación Nacional. Ciencias Sociales 5: Escuela Nueva. Bogotá, Colombia: Ministerio de Educación Nacional, 2011d.

DELGADO, L. R. J.; FRANCO, R. E. M. Colonialidad del Poder, Patriarcado y Heteronormatividad en América Latina. Revista Venezolana de Estudios de la Mujer, Caracas, v. 19, n. 42, p. 95-110, enero/jun. 2014.

ESPINOSA MIÑOSO, Y. et al. Reflexiones Pedagógicas en torno al Feminismo Descolonial: una conversa en cuatros voces. In: WALSH, C. (org.). Pedagogías Decoloniales: prácticas insurgentes de resistir, (re) existir y (re)vivir. Série Pensamiento decolonial. Quito, Ecuador: Ediciones Abya-Yala, 2013.

FERREIRA, M. G.; SILVA, J. F. Protagonismo dos Movimentos Sociais Negros na Superação da Herança Colonial nos Currículos Colonizados das Escolas Brasileiras. Revista Tópicos Educacionais, Recife, v. 20, n. 1, p. 163-185, jan./jun. 2014.

FREIRE, P. Pedagogia do Oprimido. 17. ed. Rio de Janeiro: Paz e Terra, 1987.

FREIRE, P. Pedagogia do Oprimido. 28. ed. São Paulo: Paz e Terra, 2005. 
GROSFOGUEL, R. Para descolonizar os estudos de economia política e os estudos pós-coloniais: transmodernidade, pensamento de fronteira e colonialidade global. Revista Crítica de Ciências Sociais, n. 80 , p. 115-147, mar. 2008.

MARES, T; ALMEDA, S. Geografia $2^{\circ}$ ano: Novo Girassol Saberes e Fazeres do Campo. São Paulo: FTD, 2014a. MARES, T; ALMEIDA, S. História $2^{\circ}$ ano: Novo Girassol Saberes e Fazeres do Campo. São Paulo: FID, 2014b. MARES, T.; ALMEIDA, S. História $3^{\circ}$ ano: Novo Girassol Saberes e Fazeres do Campo. São Paulo: FTD, 2014c. MARES, T.; ALMEIDA, S. História $4^{\circ}$ ano: Novo Girassol Saberes e Fazeres do Campo. São Paulo: FTD, 2014d. MARES, T; ALMEIDA, S. História $5^{\circ}$ ano: Novo Girassol Saberes e Fazeres do Campo. São Paulo: FTD, 2014e. MATOS, M.; PARADIS, C. G. Desafios à despatriarcalização do Estado brasileiro. Cadernos Pagu, Campinas, n. 43, p. 57-118, jul./dez. 2014.

MIGNOLO, W. Colonialidade: o lado mais escuro da modernidade. Revista Brasileira de Ciências Sociais, São Paulo, v. 32, n. 94, jun. 2017.

MIGNOLO, W. Historias locales/diseños globales: colonialidad, conocimientos subalternos y pensamientos fronterizo. Madrid: Akal, 2011.

MOHANTY, C. T. Bajo los ojos de occidente. Academia Feminista y discurso colonial. In: NAVAZ, L. S.; HERNÁNDEZ, A. (ed.). Descolonizando el Feminismo: Teorías y Prácticas desde los Márgenes. Madrid: Cátedra, 2008.

NARVAZ, M. G.; KOLLER, S. H. Famílias e Patriarcado: da prescrição normativa à subversão criativa. Psicologia \& Sociedade, v. 18, n. 1, p. 49-55, jan./abr. 2006.

PAREDES, J. Hilando Fino desde el feminismo comunitario. La Paz: Mujeres Creando Comunidad, 2010.

PAREDES, J. Una sociedad en estado y con estado despatriarcalizador. Cochabamba, dic. 2011.

PEIRCE, C. S. Semiótica. São Paulo: Perspectiva, 2005.

PORTO-GONÇALVES, C. W. Entre América e Abya Yala - tensões de territorialidades. Desenvolvimento e Meio Ambiente, Curitiba, n. 20, p. 25-30, jul./dez. 2009.

QUIJANO, A. Colonialidade do Poder. In: LANDER, E. (org.). A Colonialidade do Saber: eurocentrismo e Ciências sociais. Perspectivas latino-americanas. Ciudad Autónoma de Buenos Aires: CLACSO, 2005.

SAFFIOTI, H. Gênero Patriarcado Violência. São Paulo: Expressão Popular, 2015.

SAFFIOTI, H. 0 poder do macho. São Paulo: Moderna, 1987. 
SARTORELLO, S. C. Una perspectiva crítica sobre interculturalidade y educación intercultural bilingüe: El caso de la Unión de Maestros de la Nueva Educación para México (UNEM) y educadores independientes en Chiapas. Revista Latinoamericana de Educación Inclusiva, Santiago de Chile, 2009.

SEGATO, R. L. Las estructuras elementales de la violencia. Bernal: Universidad Nacional de Quilmes, 2003.

SEGATO, R. L. Patriarcado, desposesión, colonialidad y el avance del frente estatalcolonial en el mundo-aldea. Revista de Estudios Críticos Otros Logos, n. 4, dic. 2013.

TONINI, I. M. Identidades étnicas: a produção de seus significados no livro didático de Geografia. In: REUNIÃO ANUAL DA ASSOCIAÇÃO NACIONAL DE PÓS-GRADUAÇÃO E PESQUISA EM EDUCAÇÃO, 24., 2001, Caxambu. Anais [...]. Caxambu, 2001.

WALSH, C. Interculturalidad, plurinacionalidad y decolonialidad: las insurgências politico-epistémicas de refundar el Estado. Tabula Rasa, Bogotá, n. 9, 2008.

Endereços para correspondência: Rua Erasmo Xavier de Morais, Bairro Mª Auxiliadora, 85, Caruaru, Pernambuco, Brasil; aline.renata24@hotmail.com 